\title{
Residual Monomer in a Composite Resin After Light-Curing with Different Sources, Light Intensities and Spectra of Radiation
}

\author{
Ivan A. FILIPOV \\ Stoyan B. VLADIMIROV \\ Department of Operative Dentistry and Endodontology, Faculty of Dentistry, Medical University, Plovdiv, Bulgaria
}

The purpose of this study was to investigate the amount of residual monomer in a composite resin after lightcuring with different sources, light intensities and spectra of radiation. The resin specimens (4 mm in diameter; 2 $\mathrm{mm}$ thick) ( $\mathrm{n}=5$ ) were inserted in Plexglass matrixes and light-cured with a halogen lamp, LED and PAC units for 40, 40 and $5 \mathrm{~s}$, respectively. The polymerized specimens were ground and $25 \mathrm{mg}$ of each specimen were immersed in $8 \mathrm{~mL}$ 96\% ethanol for $24 \mathrm{~h}$ to extract the residual monomer. The amount of residual monomer was determined by the standard straight line method. The light spectrum of the different LCUs was shot and processed through researches of the absorbation of the standard solutions at a level of $\lambda=275 \mathrm{~nm}$ and their extracts. Data were analyzed statistically by variational dispersion analysis and Tukey-Kramer test at $5 \%$ significance level. It was observed that, the halogen lamp produced the smallest amount of monomer under sufficient light intensity. The spectrum of light radiation of PAC was within the limits of 450- $490 \mathrm{~nm}$ and was of extremely high intensity. This imposes the use of short-limited light impulses, but also might lead to deterioration quality of polymerization. The LED unit had the best spectral radiation. An increase of light intensity was proved necessary.

Key Words: light-curing unit, light intensity, radiation spectrum, residual monomer, composite resin.

\section{INTRODUCTION}

The visible light-activated resins dental composites were introduced in the 1970's. According to Swartz et al. (1), however, their emissions tend to decrease with time. Ultraviolet energy has a limited penetration within the dental structures and even within the composite itself (2). Eye injuries in cases of extreme exposures to the irradiation are also possible, as well.

These disadvantages prompted the development of composites with camphorquinone, a catalyst of the polymerizing reaction. It is sensitive to the blue light of the visible spectrum (wavelength ranging from 400 to $520 \mathrm{~nm}$ ) (2).The light $468 \mathrm{~nm}$ wavelength causes camphorquinone activation at the highest degree, which produces free radicals in combination with amines. Ultimately, the resin monomers polymerize on molecular level (3).

Polymerization starts and continues when light intensity is enough to support camphorquinone in stimulated state (4). According to ISO standard (5), the wavelength of the irradiating light must be in the 400 -

Correspondence: Dr. Ivan A. Filipov, Department of Operative Dentistry and Endodontology, Faculty of Dentistry, Medical University, Veliko Tarnovo Street 24, Plovdiv, Bulgaria. Tel: +359-32-611-4225. e-mail: filipov@abv.bg 
$510 \mathrm{~nm}$ range and a minimal energy density of $300 \mathrm{~mW} /$ $\mathrm{cm}^{2}$ is required. When composite materials are lightcured for the time recommended by the manufacturer, the induration must be $1.5 \mathrm{~mm}$ in depth. There is no correlation between the superficial induration and the depth of cure $(4,6)$. Even low-intensity light sources provide a well hardened surface, which can hide partially or totally unpolymerized material underneath.

High content of residual monomer and unsatisfactory blend of monomer-polymer (about 3577\%) of composite materials lead to several negative physical and biological properties, such as abrasive instability, tendency to color loss, high toxicity to the pulp and other (7).

Most of currently available curing procedures depend directly on the use of light-curing units (8). Conventional halogen light-curing units were introduced in the 1970's (9) and soon became a standard in composite polymerization (10). Several factors, however, can reduce significantly their light irradiation, i.e., decrease of tension, degradation of bulb and reflectors, filter damage, braking of the body or the pinnacle of the light source.

The blue light emitting diodes (LED) offer an extremely long and relatively constant and stable emission of energy stream of the blue spectrum of the visible light. However, although LEDs have been considered as promising alternative sources for curing of resin composites, a consensus has not yet been reached regarding the quality of the materials polymerized with these devices (3,11-13).

The desire to shorten the curing time has prompted the development of plasma arc curing units (PAC) $(9,14)$. However, like laser devices, PAC units are still demanding, expensive and require special protective measures (15).

The purpose of this study was to determine the amount of residual monomer in composite resins lightcured with different sources (halogen, LED, PAC units), light intensities and spectra of radiation.

\section{MATERIAL AND METHODS}

The following light-curing units were tested in this study: Polofil Lux halogen lamp (Voco, Cuxhaven, Germany). This device has an output energy of 440 $\mathrm{mW} / \mathrm{cm}^{2}$ with a standard light guide with diameter of 8 $\mathrm{mm}$. Light irradiation is constant during the whole working cycle; Optica Laser LED light-curing unit (Optica Laser Eng. Ltd. Bulgaria). This device has 7 diodes and a 5-mm-diameter turbo-type light guide. Light irradiation with this device is the so called softstart polymerization, i.e., during the first $10 \mathrm{~s}$ the unit works with half energy density and then with full energy density (88 mW/cm2); Apollo 95E PAC light-curing unit (Dental Medical Diagnostic System Inc., Irvine, CA, USA), which works with a reduced energy density during the first $1.5 \mathrm{~s}$ and with full energy density (1239 $\mathrm{mW} / \mathrm{cm}^{2}$ ) during the remaining $3.5 \mathrm{~s}$.

Plexglass matrixes (4 $\mathrm{mm}$ in diameter; $2 \mathrm{~mm}$ thichk) were used for specimen preparation. The matrixes were set on a smooth glass plate, filled with a hybrid, type II, radiopaque, light-cured composite resin (Illumine; Ortho Plus, France; $\mathrm{C}_{1}$ shade) and covered with transparent mylar strips under slight pressure to remove excess material. Thereafter, the resin specimens $(n=5)$ were light-cured with the halogen lamp, LED and PAC units for 40,40 and $5 \mathrm{~s}$, respectively.

The polymerized specimens were ground and 25 mg of each specimen were immersed in $8 \mathrm{~mL} \mathrm{96 \%}$ ethanol for $24 \mathrm{~h}$ to extract the residual monomer. The amount of residual monomer was determined by the standard straight line method. The light spectrum of the different LCUs was shot and processed through absorbation essays of the standard solutions at a level of $\lambda=275 \mathrm{~nm}$ and their extracts. Bisphenol A glycerolate (FW 484,55; Aldrich, Chem. Co., Germany) was used for preparation of the standard solutions. Varian Cary UV-Vis spectrophotometer (Varian Inc., Cary, NC, USA) was used for measuring the absorbation of the extracts by $\lambda=275 \mathrm{~nm}$ and a length of the optic way = $1 \mathrm{~cm}$.

Light intensity of the halogen and LED units were measured with a radiometer (Cure Rite Efos, model 8000, range: 0-1000 mW/cm; Efos Inc., Mississauga, Ontario, Canada) three consecutive times. This guarantees stabilization of the irradiation, even though LED units have permanent radiation and are not affected by the change in voltage.

The PAC unit produces a high light radiation that could not be read by the digital radiometer used in this study (Cure Rite Efos; Efos Inc.). That is why we accepted the values given in a previous study (1239 $\left.\mathrm{mW} / \mathrm{cm}^{2}\right)(16)$.

Data were analyzed statistically by variational dispersion analysis and Tukey-Kramer test at 5\% 
significance level using MS Excel software version 97 (Microsoft, Seattle, WA, USA) and Graphpad Insta version 2 statistical software package (Graphpad Software, San Diego, CA, USA).

\section{RESULTS}

Light spectra of the radiation of the tested lightcuring units are given in Figure 1.

The amount of residual monomer in $\mu \mathrm{g} / \mathrm{mL}$ (and standard deviation) in the composite specimens after polymerization were the following: halogen lamp (23.214 \pm 0.458), LED (30.784 \pm 1.029$)$ and PAC (29.278 \pm $0.362)$.

\section{DISCUSSION}

The light-curing units tested in this study differed in several aspects.

Polofix Lux halogen lamp proved to be a typical representative of the halogen technology for polymerization composite materials. It is in compliance with ISO standards (5) and the least amount of residual monomer observed in the specimens polymerized with this source $(23.214 \pm 0.458 \mu \mathrm{g} / \mathrm{mL})$ was within the expectations. It has to be highlighted the significant shift of the irradiation peak (494.05 nm), which is probably due to the quality of the filter. The filter should allow passage of the visual blue light only, but it can degrade with time. Passage of ultraviolet and infrared radiation through the filter might have a negative influence on both the polymerization process and the operator.

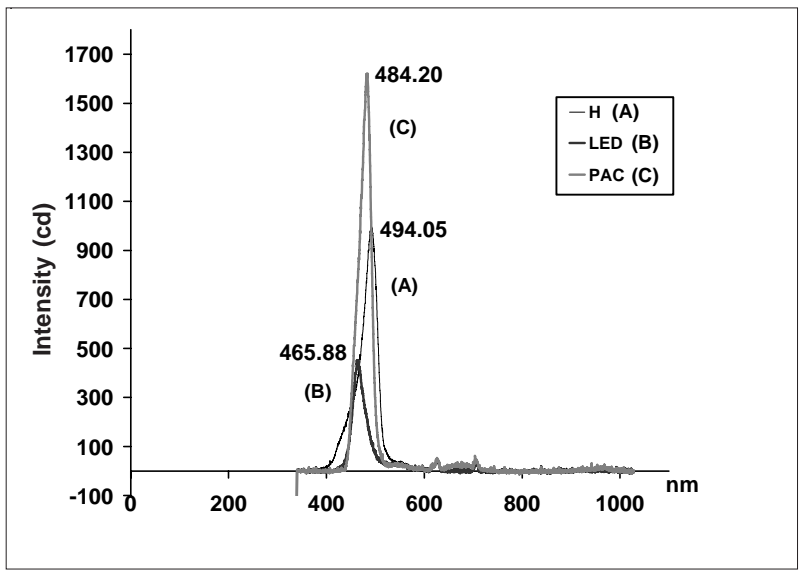

Figure 1. Light radiation spectra of the tested light-curing units.
An advantage of LED units is the absence of a filter because the diodes irradiate only in the blue spectra of the light. The LED unit used in this study renders a rush irradiation of $465.88 \mathrm{~nm}$, which almost coincides with the wavelength for camphoroquinone activation $(468 \mathrm{~nm})$. It does not differ, by this index, from some of the most eminent LED lights (CoolBlu, Apolloe and Lux-O-Max) (17). The irradiation is in narrower borders of light spectrum compared to the halogen LCU. This is positive because it increases the effectiveness of the irradiation, although it limits the applications of this device. Some dental composites (e.g., Solitaire; Heraeus Kulzer, Wehrheim, Germany) have initiators out of the spectrum covered by LED lamps, which will lead to incomplete polymerization of the material (15). It has been shown that the significance a 450-490 nm wavelength range decreases with the increase of irradiation time (18). The complete engulfment of the light by camphoroquinone as well as the saturation of the light spectrum with light of enough intensity (especially in the 450-490 $\mathrm{nm}$ range) has a decisive importance especially in the initial phase of polymerization. Despite the very good wavelength reached by the LED unit, the contemporary turbo-type light-guide and soft-start system, the specimens polymerized with this unit presented the greatest amount of residual monomer (30.784 $\pm 1.029 \mu \mathrm{g} / \mathrm{mL}$ ). This was probably due to its low energy density $\left(88 \mathrm{~mW} / \mathrm{cm}^{2}\right)$. It has been shown that the low intensity of the irradiation decreases the polymerization stress especially at adhesive interface, which ensures a better marginal adaptation, but leads to worse material physical properties and incomplete polymerization (19). Improved LED-cured restorations can be attained with increase of irradiation time. Further research should be carried on this research line.

LED units are constantly developed and now some of them have an intensity level that equals that of halogen lamps. Devices using single, highly intensive diodes, instead of ordered groups of 7, 25, 63 diodes, have been introduced. However, these units generate heat that forced the manufacturers to add a cooler to the apparatus.

The PAC unit used in this study has a very large light intensity, which assumes a good polymerization potential. Moreover, light irradiation spectrum (484.93 $\mathrm{nm}$ ) is closer to that camphoroquinone and it is in narrow borders in comparison to the halogen lamp. In spite of this, the amount of residual monomer recorded 
for the specimens light-cured with this device (29.278 $\pm 0.362 \mu \mathrm{g} / \mathrm{mL}$ ) was statistically greater than that obtained with the halogen lamp. It may be speculated that this result was due to the short curing time (5 s).

A previous study using similar methodology to this one (19) measured and compares elution of monomers from an experimental BisGMA-TEGDMA resin and a commercial resin composite when cured with a halogen unit and when cured with a plasma arc unit. The elution from resin specimens and from resin composite specimens cured with the plasma arc light unit was 7 and 4 times higher, respectively, compared to the elution from specimens cured with the halogen unit. It was concluded that the plasma arc light curing unit did not provide optimal cure when used as recommended by the manufacturer. Similar results have been found regarding composite hardness (20). The increase of exposure time, however, can cause damage to the pulp and periodontal tissues.

Ideally, a light-curing unit should polymerize the restorative as desired by the dentist during construction of a restoration and maintain a fine biological acceptance. The findings of this study showed that halogen lamp produced the least amount of monomer under sufficient light intensity, but radiation peak and its values are not in accordance with the current requirements. Light radiation spectrum of PAC unit was within the 450-490 nm limits and presented an extremely high intensity. This imposes the use of short-limited light impulses, but also deteriorates the quality of polymerization.

The LED unit had the best radiation spectrum. Its soft-start mechanism of polymerization was of great importance. However, an increase in light intensity is necessary. Given the fact that the LED technology continues to develop, it seems that it will play a leading role in the future.

The outcomes of this investigation might be of help for dentists in their choice for the most suitable light-curing for their practice.

\section{RESUMO}

O objetivo deste trabalho foi investigar a quantidade de monômero residual em resinas compostas fotopolimerizadas, empregando diferentes fontes de energia, variadas intensidades e espectros de radiação. As amostras de resina (4 $\mathrm{mm}$ de diâmetro e $2 \mathrm{~mm}$ de espessura) foram fabricadas em matrizes de Plexglass e polimerizadas com lâmpada halógena, LED e PAC por 40, 40 e 5 $\mathrm{s}$, respectivamente. As amostras foram pulverizadas e $25 \mathrm{mg}$ de cada uma foi imersa em $8 \mathrm{~mL}$ de etanol a $96 \%$ por $24 \mathrm{~h}$ para extração do monômero residual. A quantidade de monômero residual foi determinada pelo método padrão de linha reta. O espectro luminoso das diferentes fontes de energia foi projetado e analisado pelo espectro de absorção de soluções-padrão no comprimento de onda $\lambda=275 \mathrm{~nm}$. Os dados foram analisados estatisticamente pela dispersão de variância e pelo teste de TukeyKramer com nível de significância de 5\%. Constatou-se que a lâmpada halógena resultou na menor quantidade de monômero residual com luz de intensidade suficiente. O espectro de radiação do PAC esteve entre 450 e $490 \mathrm{~nm}$ e foi de intensidade extremamente alta. Este fato impõe que sejam utilizados pulsos de curta duração, mas também pode levar à deterioração da polimerização. O LED apresentou o melhor espectro de radiação. Constatou-se a necessidade de aumentar a intensidade da luz.

\section{ACKNOWLEDGEMENTS}

The authors express their sincere gratitude to Dr Ivan Angelov, working with Vigodent Ltd., Sofia, Bulgaria for his cooperation in photographing light spectra and to Jordanka Uzunova, Assistant Professor of the Department of Chemistry and Biochemistry of the Medical University, Plovdiv, Bulgaria, for her help in identifying the amount of residual monomer. The authors also acknowledge companies that supplied the LCUs used in this study.

\section{REFERENCES}

1. Swartz M, Phillips R, Rhodes B. Visible light-activated resins - depth of cure. J Am Dent Assoc 1983;106:634-637.

2. Belvedere P. Contemporary posterior direct composites using state- of- the- art techniques. Dent Clin North Am 2001;45:49-70.

3. Mills R, Jandt K, Ashworth S. Dental composite depth of cure with halogen and blue light emitting diode technology. $\mathrm{Br}$ Dent J 1999;186:388-391.

4. Caughman F, Rueggeberg F, Curtis J. Clinical guidelines for photocuring restorative resins. J Am Dent Assoc 1995;126:1280-1286.

5. Fan P, Schumacher R, Azzolin K, Geary R, Eichmiller F. Curing-light intensity and depth of cure of resin based composites tested according to international standards. J Am Dent Assoc 2002;133:429-435.

6. Shortall A, Harrington E. Guidelines for the selection, use, and maintenance of visible light activation units. Br Dent J 1996;180:383-386.

7. Spahl W, Budzikiewicz H, Geurtsen W. Eine Untersuchung zum Restmonometer - und Additivagehalt verschiedener lichthärthender Hybridkomposite. Dtsch. Zahnärzt 1991;46:471-475.

8. Stahl F, Ashworth S, Jandt K, Mills R. Light-emitting diode (LED) polymerization of dental composites: flexural properties and polymerization potential. Biomaterials 2000;21:1379-1385.

9. Christensen G. The curing-light dilemma. J Am Dent Assoc 2002;133:761-763.

10. Ernst C. Blue light... a better cure? DPREurope 2002;14-17.

11. Jandt K, Mills R, Blackwell G, Ashworth S. Depth of cure and 
compressive strength of dental composites cured with blue light emitting diodes (LEDs). Dent Mater 2000;6:41-47.

12. Dunn W, Bush A. A comparison of polymerization by light emitting diode and halogen- based light curing units. J Am Dent Assoc 2002;133:335-341.

13. Christensen G. Curing restorative resin- a significant controversy. J Am Dent Assoc 2000;131:1067-1070.

14. Mills R, Uhl A, Jandt K. Optical power outputs, spectra and dental composite depths of cure, obtained with blue light emitting diode (LED) and halogen light cutting units (LCUs). Br Dent J 2002;193:459-463.

15. Christensen GJ. The light curing mania J Am Dent Assoc 2004;135;461-463.

16. Mills RW, Uhl A, Jandt KD. Optical power outputs, spectra and dental composite depths of cure, obtained with blue light emitting diode (LED) and halogen light curing units (LCUs). Br Dent J 2002;193:459-463.
17. Nomoto R. Effect of light wavelength on polymerization of light-cured resins. Dent Mater J 1997;16:60-73.

18. Uno S, Tanaka T, Natsuizaka A, Abo T. Effect of slowcutting on cavity wall adaptation using a new intensitychangeable light source. Dent Mater 2003;19:147-152.

19. Munksgaard E, Peutzfeldt A, Asmussen E. Elution of TEGDMA and BisGMA from a resin composite cured with halogen or plasma light. Eur J Oral Sci 2000;108:341-345.

20. Correr AB, Sinhoreti MAC, Sobrinho LC, Tango RN, Schneider LFJ, Consani S. Effect of the increase of energy density on Knoop hardness of dental composites light-cured by conventional QTH, LED and xenon plasma arc. Braz Dent J 2005;16:218-224.

Accepted July 4, 2004 